\section{Managing Potassium for Organic Crop Production}

\author{
Robert L. Mikkelsen ${ }^{1}$
}

ADDITIONAL INDEX WORDS. greensand, langbeinite, manure, rock powder, seaweed, sylvinite, ash

Summary. An adequate potassium (K) supply is essential for both organic and conventional crop production. Potassium is involved in many plant physiological reactions, including osmoregulation, protein synthesis, enzyme activation, and photosynthate translocation. The $\mathrm{K}$ balance on many farms is negative, where more $\mathrm{K}$ is removed in harvested crops than is returned to the soil. Although various organic certification agencies have different regulations governing allowable sources of $\mathrm{K}$, the behavior of soil $\mathrm{K}$ is largely governed by its solubility. The slow release of $\mathrm{K}$ from soil minerals is often insufficient to meet the peak nutrient demand of high-yielding crops, but they can contribute to the long-term improvement of soil fertility. There are many excellent $\mathrm{K}$ sources allowed for organic crop production, including soluble minerals such as langbeinite, sylvinite, and potassium sulfate. Potassium sources such as wood ash, greensand, and seaweed can also supply $K$ but require special management because of their low nutrient content, their effect on soil $\mathrm{pH}$, low solubility, or bulky nature. The concentration of $\mathrm{K}$ in manures and composts is highly variable, but it is generally quite soluble and available for plant uptake. Some rock minerals may supply a portion of the K requirement of plants, but many are too insoluble to be of practical significance.

$\mathrm{P}$ otassium $(\mathrm{K})$ is an essential nutrient for plant growth, but it generally receives less attention than nitrogen $(\mathrm{N})$ and phosphorus $(\mathrm{P})$ in many crop production systems. Many regions of the United States and all of the Canadian provinces remove more $\mathrm{K}$ from the soil during harvest than is returned to the soil in fertilizer and manure (Fig. 1). In the United States, an average of only $3 \mathrm{~kg} \mathrm{~K}$ is replaced as fertilizer and manure for every $4 \mathrm{~kg} \mathrm{~K}$ removed in crops [Potash and Phosphate Institute (PPI), 2002]. This net export of $\mathrm{K}$ in harvested crops ultimately results in a depletion of nutrients from the soil and increasing occurrences of deficiency.

Potassium is the soil cation required in the largest amount by plants, regardless of nutrient management philosophy. Large amounts of $\mathrm{K}$ are required to maintain plant health and vigor. Some specific roles of $\mathrm{K}$ in the plant include osmoregulation, internal cation/anion balance, enzyme activation, and proper water relations. Potassium plays a vital role in photosynthate translocation, especially to grains, tubers, and fruit. Protein synthesis is facilitated with

International Plant Nutrition Institute (IPNI), 4125 Sattui Court, Merced, CA 95348

${ }^{1}$ E-mail: rmikkelsen@ipni.net. an adequate supply of $\mathrm{K}$. Tolerance of external stress such as frost, drought, heat, and high light intensity is enhanced with proper $\mathrm{K}$ nutrition. Stresses from disease and insect damage are also reduced with an adequate supply of $\mathrm{K}$. Although there are no known harmful effects of $\mathrm{K}$ to the environment or to human health, the consequences of inadequate $\mathrm{K}$ can be severe for crop growth and efficient utilization of other nutrients such as $\mathrm{N}$ and $\mathrm{P}$. Maintenance of adequate $\mathrm{K}$ is essential for both organic and conventional crop production.

Supplemental $\mathrm{K}$ is sometimes called "potash," a term that comes from an early production technique in which $\mathrm{K}$ was leached from wood ashes and concentrated by evaporating the leachate in large iron pots (Mikkelsen and Bruulsema, 2005). Clearly, this practice is no longer practical and is not environmentally sustainable. This potash collection method depended on the tree roots to deplete the soil of $\mathrm{K}$, which was then recovered from the wood after it was harvested and burned. Large amounts of wood were burned to collect relatively little potash. Today, most $\mathrm{K}$ fertilizer, whether used in organic or conventional agriculture, comes from ancient marine salts deposited as inland seas evaporated. This natural geological process is visible today in places such as the Great Salt Lake and the Dead Sea, as illustrated in Figure 2.

\section{Organic crop production}

The basic principles of plant nutrition are the same, whatever the production system used. Both organic and conventional production systems have many common objectives and generally work with the same basic global resources. Although specific nutrient management techniques and options may vary between the two systems, the fundamental processes supporting soil fertility and plant nutrition do not change (Stockdale et al., 2002).

In general, the objectives of organic plant nutrition are to 1 ) work within natural systems and cycles, 2) maintain or increase long-term soil fertility, 3) use renewable resources as much as possible, and 4) produce food that is safe, wholesome, and nutritious.

For some nutrients such as $\mathrm{K}$ and $\mathrm{P}$, there are not many differences between management of conventional and organic production, except for some of the allowable nutrient sources. Organic regulations require growers to rely on the use of untreated products for supplying $\mathrm{K}$, where conventional producers have a wider range of materials available to maintain soil fertility and meet crop nutrient demands. The greatest differences between the two production systems likely occur with $\mathrm{N}$ management.

\section{Which organic standards should be followed?}

The use of approved nutrient sources is governed by a variety of oversight organizations. In the

\begin{tabular}{llll}
\hline $\begin{array}{l}\text { Units } \\
\begin{array}{l}\text { To convert U.S. to SI, } \\
\text { multiply by }\end{array}\end{array}$ & U.S. unit & SI unit & $\begin{array}{l}\text { To convert SI to U.S., } \\
\text { multiply by }\end{array}$ \\
\hline 10 & $\%$ & $\mathrm{~g} \cdot \mathrm{kg}^{-1}$ & 0.1 \\
0.4536 & $\mathrm{lb}$ & $\mathrm{kg}$ & 2.2046 \\
0.5 & $\mathrm{lb} / \mathrm{ton}$ & $\mathrm{kg} \cdot \mathrm{mg}^{-1}$ & 2
\end{tabular}




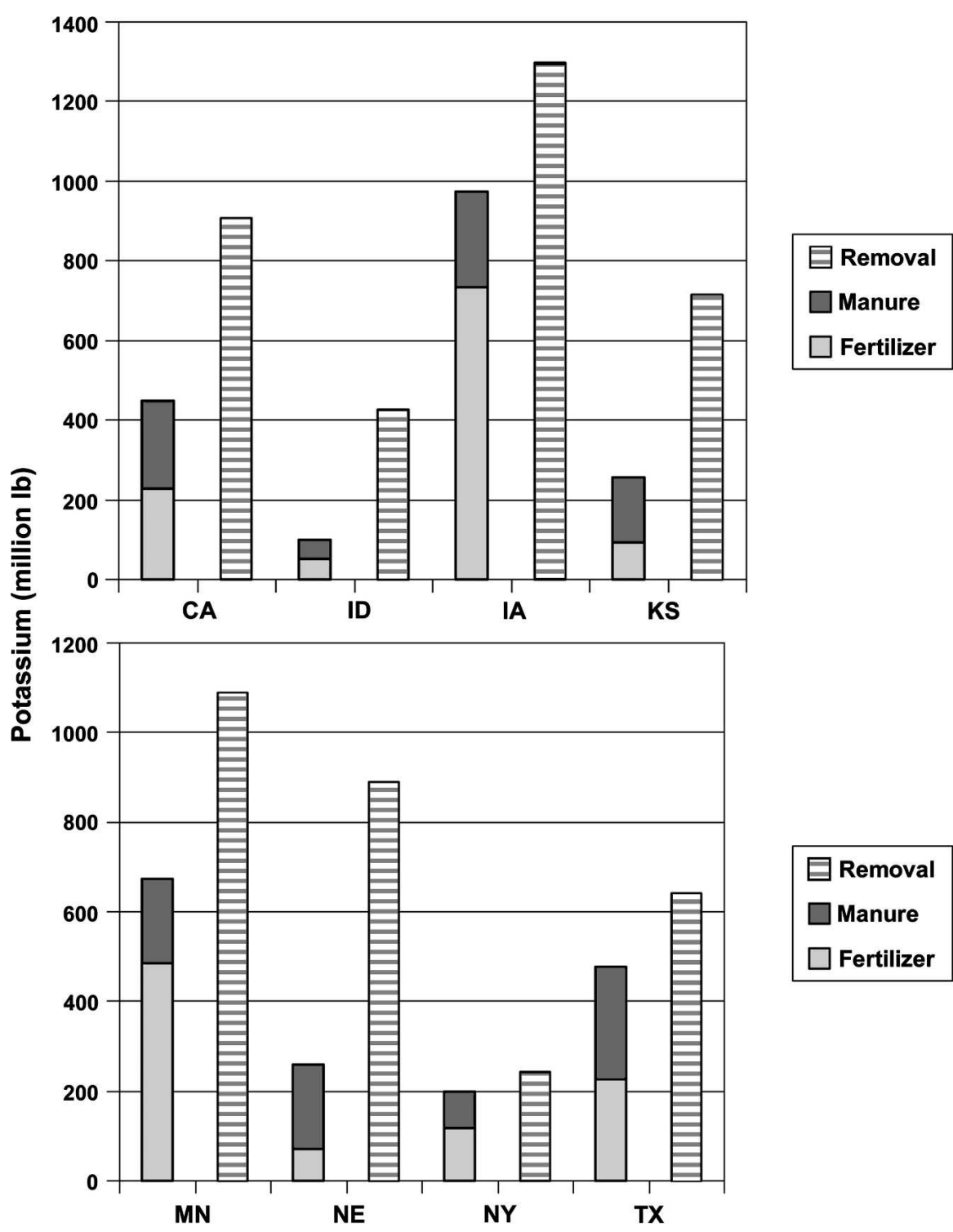

Fig. 1. Annual balance of potassium (K) inputs in fertilizer and recoverable manure compared with $\mathrm{K}$ removal in harvested crops in eight selected U.S. states: California (CA), Idaho (ID), Iowa (IA), Kansas (KS), Minnesota (MN), Nebraska (NE), New York (NY), and Texas (TX) (Potash and Phosphate Institute, 2002); $1 \mathrm{lb}=0.4536 \mathrm{~kg}$.

United States, the U.S. Department of Agriculture (USDA) National Organic Program [NOP (USDA, 2007a)] is responsible for setting and maintaining standards. In Canada, the Canadian General Standards Board (CGSB, 2006) oversees the organic production systems program. In Europe, the major organizations include International Federation of Organic Agriculture Movements and Codex Alimentarius (a cooperative effort of the Food and Agricultural Organization and the World Health Organization of the United Nations). Each of these organizations maintains somewhat different standards and allows different materials to be used in their organic production systems because they individually interpret the intent of organic agricultural principles (Heckman, 2006). As a result, a grower seeking advice on permissible organic materials should first know where the agricultural produce will be sold to meet the requirements of that market.

In general, regulations for mined $\mathrm{K}$ sources specify that they must not be processed, purified, or altered from their original form. However, there is disagreement among different certifying bodies over what specific materials can be used. Unfortunately,

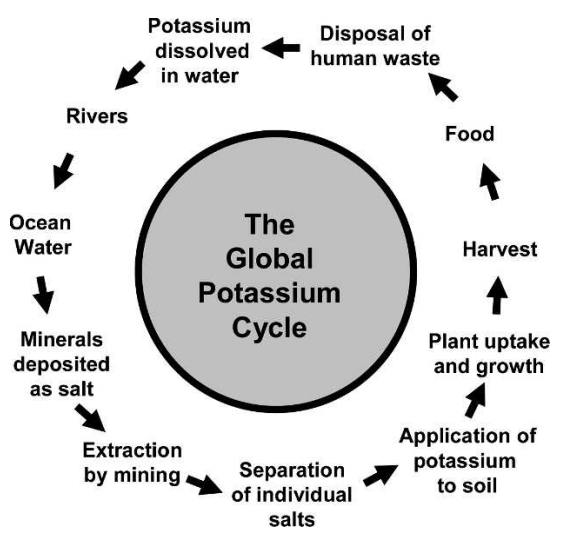

Fig. 2. The global potassium cycle.

some of these restrictions on certain nutrient materials do not have solid scientific justification, and their inclusion or exclusion on various lists should not be viewed as one material being more or less "safe" than another fertilizer material.

\section{A variety of organic production systems}

There are many variations possible for successful K management in organic production systems (Askegaard et al., 2004). The largest differences occur on farms that produce both livestock and crops compared with farms that strictly produce crops for off-farm sale. In the mixed livestock/ crop systems, the nutrition of the animals generally takes first priority and the residual manure is returned to surrounding cropland. In these cases, imported $\mathrm{K}$ in feed and bedding frequently exceeds the output in milk and meat products, sometimes leading to an accumulation of $\mathrm{K}$ in the surrounding fields that receive manure. Large losses of $\mathrm{K}$ often occur on these farms during manure storage and composting. Because excreted $\mathrm{K}$ mostly goes into urine, if this fraction is not effectively recovered, it will not be returned to the field with the solid portion of the manure.

Crop rotations are a central part of organic production systems. Although this practice can be helpful for supplying $\mathrm{N}$ when legume crops are included and may also reduce $\mathrm{K}$ leaching losses, rotations alone do not supply any additional $\mathrm{K}$ to the farm. Plant roots have been shown to enhance soil mineral weathering by depleting rhizosphere $\mathrm{K}$ and causing a shift in the Kequilibrium. This shift 
can speed natural processes and enhance the rate of clay transformations (Hinsiger and Jaillard, 1993). Subsoil K reserves may be important for some crop rotation systems where deep-rooted plants can extract K, which may be subsequently used by shallow-rooted crops (Witter and Johansson, 2001). Although rotational crops may influence the availability of existing soil $\mathrm{K}$, the removal of any plant material from the field continually depletes the soil nutrient supply and ultimately reduces the long-term productivity.

Plant-available $\mathrm{K}$ is usually measured in the topsoil, but some deeprooted plant species can take up considerable amounts of $\mathrm{K}$ from the subsoil (Kuhlman, 1990). The contribution of subsoil $\mathrm{K}$ to the plant $\mathrm{K}$ requirement depends on the amount of plant-available $\mathrm{K}$ in the top and subsoil, potential root-limiting factors (such as compaction, salinity, or acidity), and the root distribution pattern of the specific crop. Soil testing done near the soil surface layer will not account for this subsoil contribution to the K supply.

It is important to define the "sustainability" of using native soil $\mathrm{K}$ resources as a long-term nutrient source. Does sustainable $\mathrm{K}$ management mean not depleting the exchangeable $\mathrm{K}$ to a point at which mineral $\mathrm{K}$ begins to supply the plant with $\mathrm{K}$ ? Is the removal of exchangeable $\mathrm{K}$ acceptable as long as it is replaced with $\mathrm{K}$ from less available pools? Is it sustainable to use fossil fuels to transport low K-containing materials to areas where native soil $\mathrm{K}$ supplies are low? There are many complex issues that interact to determine long-term sustainability (Bergstrom et al., 2005).

\section{Potassium balance}

Because off-farm sales will always lead to a depletion of $K$ and some additional loss of $\mathrm{K}$ through leaching and runoff is inevitable, the potential of a cropping management system to resupply the $\mathrm{K}$ reserve is important (Oborn et al., 2005). The use of farm budgets may be most useful for describing the nutrient flow within a farming system and to assist with nutrient planning for long-term rotations and mixed farming systems. Depending on a variety of factors, the on-farm budgets of $\mathrm{N}, \mathrm{P}$, and $\mathrm{K}$ on organic farms have been shown to range from a surplus to a deficit (e.g., Bengtsson et al., 2003; Watson et al., 2002).

For example, a survey of four long-term organic farms in England showed that soil $\mathrm{K}$ concentrations were continually dropping, because the harvested crops extracted the reserves of $\mathrm{K}$ and $\mathrm{P}$ that were built up during the previous years when the farms were operated with conventional management (Gosling and Shepherd, 2005). Although some excellent nutrient budgets have been developed for European organic farms, relatively little of this work has been done in North America.

The demand for $\mathrm{K}$ by various crops has been well established by measuring the $\mathrm{K}$ concentration in the harvested portion of the crop (Table 1). However, much less attention has been paid to the rate at which K must be supplied to the plant. Both the total amount required (quantity) and the rate of supply (intensity) are equally important. This concept is important for all crop growth but requires special attention when using low-solubility nutrient sources that may provide an adequate amount of total $\mathrm{K}$, but not at a rate sufficiently rapid to meet peak-demand periods of plant growth.

A summary of 3.4 million soil samples from across North America, which had been analyzed by 70 major soil testing laboratories before the 2005 growing season, was compiled (PPI, 2005). On average, 39\% of the submitted samples require additional $\mathrm{K}$ to avoid yield loss by most major crops (Fig. 3). If a typical "buildmaintenance" soil fertility program is followed, then $52 \%$ of the samples should receive at least as much $\mathrm{K}$ as is removed in the harvested crops. Supplemental K was most often needed in the southeastern United States and least often needed in the central Great Plains.

Nebraska shows the lowest frequency of $\mathrm{K}$ need at $6 \%$, whereas Georgia shows the highest frequency of $77 \%$. These regional differences are attributable primarily to indigenous soil properties. The central Great Plains and much of western North America generally have high-K soils resulting from the prevailing climate and the dominance of soils that have developed from high-K parent materials. However, crop removal of $\mathrm{K}$ over many decades is significantly reducing soil K levels in these regions. On the other hand, the southeastern United States experiences a more intense weathering environment and has soils developed from parent materials lower in $K$ and with a limited capacity to retain plant-available $\mathrm{K}$. These general regional trends can provide insight but must not be used to make specific recommendations on individual fields.

\section{Potassium release from soil minerals}

The most common mineral sources of $\mathrm{K}$ in soils are feldspars and micas, soil minerals remaining from the primary parent material. Weathering of these primary minerals produces a range of secondary minerals that may also serve as a source of $\mathrm{K}$ in soil. These minerals include micaceous clays such as illite and vermiculite.

The release of $\mathrm{K}$ from micas proceeds by two processes (Sparks, 1987): 1) K-bearing micas transform to expandable 2:1 layer silicates after the replacement of $K$ with hydrated

Table 1. Average potassium (K) removal in the harvested portion of some common agronomic and horticultural crops. ${ }^{\mathrm{z}}$

\begin{tabular}{llc}
\hline Crop & \multicolumn{1}{c}{ Scientific name } & K removal (lb/ton $)^{\mathbf{y}}$ \\
\hline Alfalfa & Medicago sativa & 50 \\
Almond & Prunus dulcis & 90 \\
Corn grain & Zea mays & 9 \\
Corn silage & Zea mays & 7 \\
Potatoes & Solanum tuberosum & 10 \\
Spinach & Spinacia oleracea & 11 \\
Squash & Cucurbita pepo & 10 \\
Rice & Oryza sativa & 7 \\
Tomatoes & Lycopersicon esculentum & 6 \\
Wheat & Triticum aestivum & 10 \\
\hline
\end{tabular}

${ }^{\mathrm{z}}$ International Plant Nutrition Institute, 2007; USDA, 2007b.

${ }^{\mathrm{y}} \mathrm{lb} / \mathrm{ton}=0.5 \mathrm{~kg} \cdot \mathrm{mg}^{-1}$. 


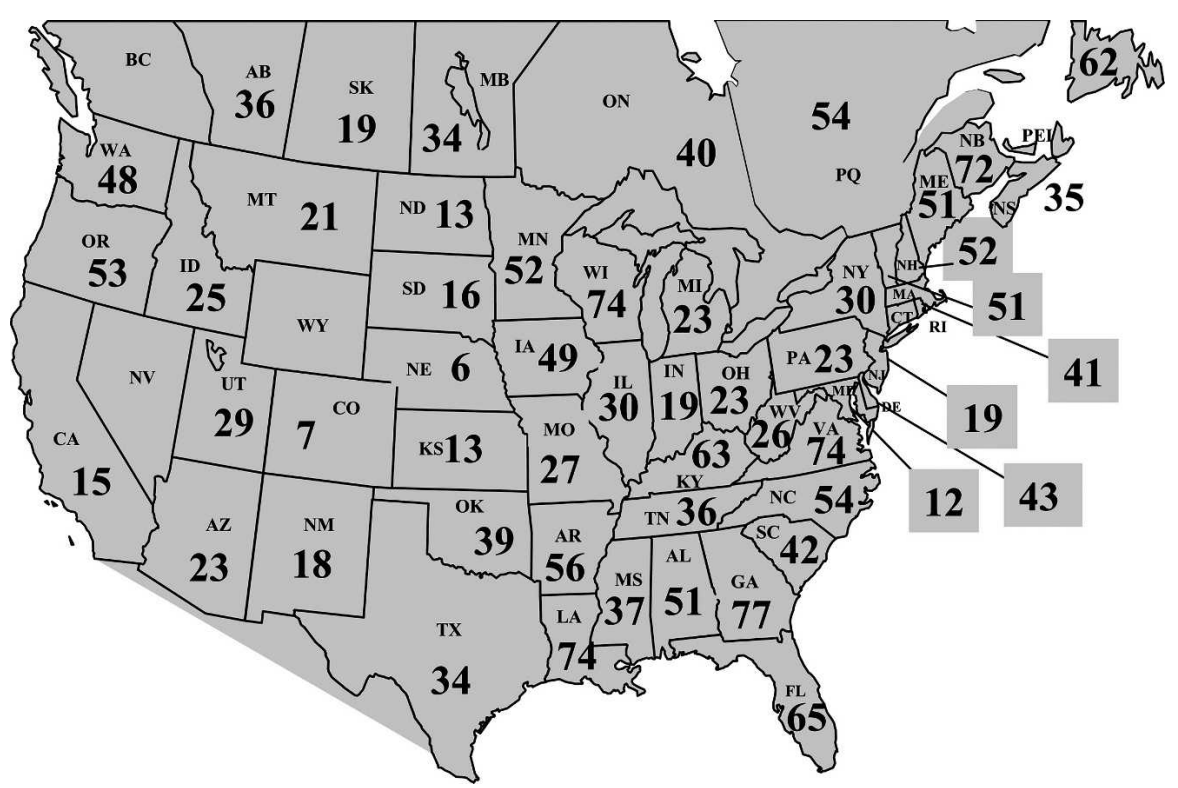

Fig. 3. The percentage of soils requiring potassium $(K)$ fertilization to avoid yield loss for major North American crops in 2005 (soils testing medium or lower in K) (Potash and Phosphate Institute, 2005).

cations. This occurs through clay-edge weathering or clay-layer weathering; and 2) weathering of the mica (releasing $\mathrm{K}$ ) and the subsequent formation of secondary weathering products.

Soils with high clay content are sometimes associated with high reserves of $\mathrm{K}$, but this is not universally true. For example, soils with montmorillonite, vermiculite, chlorite, and kaolinite clays do not have the same Ksupplying capacity as illite clays (Rao and Khera, 1994). The dynamics of $\mathrm{K}$ release from these mineral fractions has not been well established for our major production soils and is not routinely measured in soil tests.

Some soil minerals may also act as a sink for removing $\mathrm{K}$ from solution. When $\mathrm{K}$ is adsorbed in the interlayer sites of illite, vermiculite, and other smectite clays, the clay layers collapse and trap the $\mathrm{K}$ within the mineral lattice. This fixation process is relatively fast, whereas the release of this interlayer $\mathrm{K}$ is very slow (Oborn et al., 2005).

The capacity of clays to maintain a given concentration of $\mathrm{K}$ is referred to as the $\mathrm{K}$ buffer capacity (KBC). A soil with a high KBC suggests good $\mathrm{K}$ availability and a low KBC suggests a greater need for more frequent $\mathrm{K}$ addition. Clearly, the soil texture and mineralogy will be important for determining the need for $\mathrm{K}$ fertilization regardless of the type of crop management.
The soil cation exchange capacity (CEC) is determined by the amount of clay present and its mineralogy as well as the content and characteristics of the organic matter fraction. Where the CEC is increased with regular organic matter additions, the capacity of soil to retain cations, such as $\mathrm{K}$ will also be increased (Johnston, 1986). However, a high CEC does not directly translate to high productivity because many other physical and chemical properties will also change with differences in CEC.

\section{Potassium sources for organic production}

Regular applications of soluble K, regardless of the source, will increase the concentration of $\mathrm{K}$ in the soil solution and the proportion of $\mathrm{K}$ on the cation exchange sites. All of the commonly used soluble $\mathrm{K}$ sources (including manures, composts, and green manures) contain this nutrient in the simple cationic $\mathrm{K}^{+}$form. Most soluble inorganic fertilizers and organic manures are virtually interchangeable as sources of $\mathrm{K}$ for plant nutrition. When using readily available forms of $\mathrm{K}$, the overall goal of replacing the harvested $\mathrm{K}$ is generally more important than minor differences in the behavior of the $\mathrm{K}$ source. Any differences in plant performance are usually the result of the accompanying anions [such as chloride $\left(\mathrm{Cl}^{-}\right)$or sulfate $\left(\mathrm{SO}_{4}{ }^{2-}\right)$ ] or the organic matter that may accompany the added $\mathrm{K}$.

There is no general evidence that potassium sulfate $\left(\mathrm{K}_{2} \mathrm{SO}_{4}\right)$ is more effective than potassium chloride $(\mathrm{KCl})$ as a source of plant-available $\mathrm{K}$, and both $\mathrm{SO}_{4}{ }^{2-}$ and $\mathrm{Cl}^{-}$provide essential nutrients that are required for plant health. Chloride is sometimes disparaged as being harmful to soil, but there is no evidence for this claim at typical rates of application. It has a well-documented role in improving plant health and prevention of a variety of plant diseases (Fixen, 1993). Chloride-derived salinity was the same as sulfate-based salinity on its effect on common soil microbes (e.g., Li et al., 2006) and the addition of $\mathrm{K}$ decreased the harmful effects of salinity on soil microbial activity (Okur et al., 2002).

Crushed rocks and minerals have been evaluated as K sources in several field and greenhouse experiments (Bakken et al., 1997, 2000). In general, plants are able to gain a very limited amount of $\mathrm{K}$ from minerals applied as biotite, phlogopite, muscovite, and nepheline (Sparks, 1987). Feldspar $\mathrm{K}$ is not plant-available without additional treatment or weathering. The rate of $\mathrm{K}$ release from minerals is influenced by factors such as soil $\mathrm{pH}$, temperature, moisture, microbial activity, the reactive surface area, and the type of vegetation. Therefore, a mineral that is somewhat effective as a $\mathrm{K}$ source in one condition may be ineffective in another environment. Nonexchangeable K should not be confused with mineral $\mathrm{K}$, because nonexchangeable $\mathrm{K}$ is held between adjacent tetrahedral layers of clay instead of being covalently bonded in mineral crystal structures.

Organic producers are encouraged to take a long-term perspective on soil fertility. Crops require an adequate supply of all the essential mineral nutrients for growth. High yields of crops, regardless of the production philosophy, place a large drain on the soil reserves of $\mathrm{K}$. This deficit must ultimately be replenished at some point (Gosling and Shepherd, 2005).

\section{Approved and restricted potassium sources}

The NOP program in the United States and the CGSB in Canada 
classify products as allowed, restricted, or prohibited for use in organic production. Allowed products are permitted for organic production when applied as directed on the label. Restricted materials can only be used for certain uses and under specific conditions. Prohibited products may never be used for organic production. The following $\mathrm{K}$ sources are used sometimes for organic production (Organic Materials Review Institute, 2007). The properties and value of these materials as sources of plant nutrients vary considerably.

Greensand. Greensand is the name commonly applied to a sandy rock or sediment containing a high percentage of the green mineral glauconite. Because of its K content (up to $5 \% \mathrm{~K})$, greensand has been marketed for over 100 years as a natural fertilizer and soil conditioner. The very slow $\mathrm{K}$ release rate of greensand is touted to minimize the possibility of plant damage by fertilizer "burn," whereas the mineral's moisture retention may aid soil conditioning. However, the $K$ release rate is too slow to provide any significant nutritional benefit to plants at realistic application rates (Heckman and Tedrow, 2004 ). Soluble K is generally less than $0.1 \%$ of the total $\mathrm{K}$ present. Deposits of greensand are found in several states (including Arkansas and Texas), but the only active greensand mine in North America is located in New Jersey.

LANGBEINITE [POTASSIUMMAgNESIUM SULFATE $\left(\mathrm{K}_{2} \mathrm{SO}_{4}\right.$ $\left.\mathbf{M g S O}{ }_{4}\right)$ ]. This material is allowed as a nutrient source if it is used in the raw, crushed form without any further refinement or purification. Several excellent sources of this organically approved product are available for use with organic crop production. Langbeinite typically contains $18 \% \mathrm{~K}, 11 \%$ magnesium $(\mathrm{Mg})$, and $22 \%$ sulfur (S) in forms readily available for plant uptake. The major source of langbeinite in North America is from underground deposits in New Mexico.

Manure ANd compost. Because these organic materials are extremely variable (based on their raw materials and their handling), they also contain highly variable $\mathrm{K}$ concentrations. Composted organic matter is generally allowed as a nutrient source as needed. Raw manures have restrictions on the timing of their use, but the exact details may depend on the certifying agency. The $\mathrm{K}$ in these organic materials is largely available for plant uptake, similar to approved inorganic sources. Repeated applications of large amounts of manure can result in $\mathrm{K}$ accumulation in the soil, which may result in luxury consumption of $\mathrm{K}$ in the plant. A chemical analysis of the manure or compost composition is necessary to use these resources for maximum benefit. It may be helpful to consider where the compost or manure $\mathrm{K}$ is coming from because neither composting nor animal digestion produces any nutrients.

Potassium sulfate $\left(\mathrm{K}_{2} \mathrm{SO}_{4}\right)$. When $\mathrm{K}_{2} \mathrm{SO}_{4}$ is derived from natural sources, it is allowed for organic crop production. Much of the current production of organically approved $\mathrm{K}_{2} \mathrm{SO}_{4}$ comes from the Great Salt Lake in Utah. It may not undergo further processing or purification after mining or evaporation other than crushing and sieving. This product is not allowed in some European countries without special permission from the certifying agency. It generally contains $\approx 40 \% \mathrm{~K}$ and $17 \% \mathrm{~S}$.

Rock POWDERs. Mined rocks, including ballast, biotite, mica, feldspars, granite, and greensand, are allowed without restriction. Tremendous variability exists in the $\mathrm{K}$ release rate from these mineral sources. Some of them are wholly unsuitable as $\mathrm{K}$ sources for plant nutrition because of their limited solubility and their heavy and bulky nature, whereas others may have value over long periods of time. In general, a smaller particle size translates to a greater surface area, reactivity, and weathering rate.

SEAWEED. Because sea water contains an average of $0.4 \mathrm{~g} \cdot \mathrm{kg}^{-1} \mathrm{~K}$, seaweed may accumulate up to several percent K. When harvested, seaweed biomass can be used directly as a $\mathrm{K}$ source or the soluble $\mathrm{K}$ may be extracted. These $\mathrm{K}$ sources are readily soluble and typically contain less than 2\% K. Although seaweedderived products are excellent $\mathrm{K}$ sources, their low $\mathrm{K}$ content and accompanying transportation costs can make it problematic for field-scale use, especially far from the harvesting area.
SYlVINITE [POTASSIUM CHLORIDE (KCl)]. $\mathrm{KCl}$ is restricted in the USDA standards unless it is from a mined source (such as sylvinite) and undergoes no further processing to remove sodium salts. It must be applied in a manner that minimizes $\mathrm{Cl}$ accumulation in the soil. Generally, $\mathrm{KCl}$ should only be used after consultation with the certifying agency. The Canadian CGSB has included $\mathrm{KCl}$ on the "permitted substances list" for organic food production systems. Unprocessed sylvinite often contains $\approx 17 \% \mathrm{~K}$.

Wood AsH. Ash from hardwood trees served as one of the earliest sources of $\mathrm{K}$ for building soil fertility. This highly variable material is composed of whatever elements were initially present in the wood and were not volatilized when it was burned. Wood ash is an alkaline material, with a $\mathrm{pH}$ ranging from 9 to 13 , and has a liming effect of between $8 \%$ and $90 \%$ of the total neutralizing value of commercial limestone. In terms of commercial fertilizer, average wood ash would have an analysis of $\approx 0 \%$ $\mathrm{N}, 1 \% \mathrm{P}$, and $4 \% \mathrm{~K}$. The use of ash derived from manures, biosolids, coal, and some substances is prohibited for organic production. Check with the certifying organization before applying ash to soil.

Growers using organic production practices, like all growers, have a need for an adequate supply of soil $\mathrm{K}$ to sustain healthy and highyielding crops. There are many excellent sources of $\mathrm{K}$ that are available for replacing the nutrients removed from the soil in harvested crops. Materials used as a $\mathrm{K}$ source for organic production must release the nutrient at a rate sufficient to meet the demand of the crop, but there are no commonly available procedures to predict this release rate. Soil minerals and crushed rocks may provide a source of $K$, but their release rate can be quite variable and is often inadequate prevent crop deficiency. Failure to maintain adequate $\mathrm{K}$ in the root zone will result in poor water use efficiency, greater pest problems, decreased harvest quality, and reduced yields. Regular soil testing for $\mathrm{K}$ is the key for establishing the requirement for fertilization. If a need for supplemental $\mathrm{K}$ exists, organic producers generally should first consider locally available $\mathrm{K}$ resources and supplement with mineral sources. 
The expense of transporting and applying low nutrient content amendments must also be considered.

\section{Literature cited}

Askegaard, M., J. Eriksen, and A.E. Johnston. 2004. Sustainable management of potassium, p. 85-102. In: P. Schjonning, S. Elmholt, and B.T. Christensen (eds.). Soil quality: Challenges in modern agriculture. CAB Intl., Oxford, UK.

Bakken, A.K., H. Gautneb, and K. Myhr. 1997. The potential of crushed rocks and mine tailings as slow-releasing $\mathrm{K}$ fertilizers assessed by intensive cropping with italian ryegrass in different soil types. Nutr. Cycling Agroecosystems 47:41-48.

Bakken, A.K., H. Gautneb, T. Sveistrup, and K. Myhr. 2000. Crushed rocks and mine tailings applied as $\mathrm{K}$ fertilizers on grassland. Nutr. Cycling Agroecosystems 56:53-57.

Bengtsson, H., I. Oborn, S. Jonsson, I. Nilsson, and A. Anderson. 2003. Field balances of some mineral nutrients and trace elements in organic and conventional dairy farming - A case study at Ojebyn, Sweden. Eur. J. Agron. 20:101-116.

Bergstrom, L., B.T. Bowman, and J.T. Sims. 2005. Definition of sustainable and unsustainable issues in nutrient management of modern agriculture. Soil Use Mgt. 21:76-81.

Canadian General Standards Board. 2006. Organic production systems permitted substances lists. I June 2007. <http://www.pwgsc.gc.ca/cgsb/ on_the_net/organic/032_0311_2006e.pdf>.

Fixen, P.E. 1993. Crop responses to chloride. Adv. Agron. 50:107-150.

Gosling, P. and M. Shepherd. 2005. Long-term changes in soil fertility in organic arable farming systems in Eng- land, with particular reference to $\mathrm{P}$ and $\mathrm{K}$. Agr. Ecosystems Environ. 105:425-432.

Heckman, J. 2006. A history of organic farming: Transitions from Sir Albert Howard's war in the soil to USDA National Organic Program. Renewable Agr. Food Systems 21:143-150.

Heckman, J.R. and J.C.F. Tedrow. 2004. Greensand as a soil amendment. Better Crops 88:16-17.

Hinsiger, P. and B. Jaillard. 1993. Rootinduced release of interlayer potassium and vermiculitization of phlogopite as related to potassium depletion in the rhizosphere of ryegrass. J. Soil Sci. 44:525-534.

International Plant Nutrition Institute. 2007. Nutrient removed in harvested portion of crops. 1 June 2007. <http:// www.ipni.net/nutrientremoval>.

Johnston, A.E. 1986. Potassium fertilization to maintain a $\mathrm{K}$-balance under various farming systems, p. 177-204. In: Nutrient balances and the need for potassium. 13th Congr. Intl. Potash Inst., Reims, France.

Kuhlman, H. 1990. Importance of the subsoil for the K nutrition of crops. Plant Soil 127:129-136.

Li, X.F., B. Singh, and Z. Rengel. 2006. Decomposition of maize straw in saline soil. Biol. Fertil. Soils 42:366-370.

Mikkelsen, R.L. and T.W. Bruulsema 2005. Fertilizer use for horticultural crops in the U.S. during the 20th century. HortTechnology 15:24-30.

Oborn, I., Y. Andrist-Rangel, M. Askegaard, C.A. Grant, C.A. Watson, and A.C. Edwards. 2005. Critical aspects of potassium management in agricultural systems. Soil Use Mgt. 21:102-112.

Okur, N., M. Çengel, and S. Göçmez. 2002. Influence of salinity on microbial respiration and enzyme activity of soils. Acta Hort. 573:189-194.
Organic Materials Review Institute. 2007. OMRI product list. I June 2007. <http:// www.omri.org/crops_generic.pdf>.

Potash and Phosphate Institute. 2002. Plant nutrient use in North American agriculture. Potash and Phosphate Inst., Potash and Phosphate Inst. of Canada, Foundation for Agronomic Res. Tech. Bul. 2002-1. Norcross, GA.

Potash and Phosphate Institute. 2005. Soil test levels in North America: Summary update. Potash and Phosphate Inst., Potash and Phosphate Inst. of Canada, Foundation for Agronomic Res. Tech. Bul. 2005-1. Norcross, GA.

Rao, C.S. and K.S. Khera. 1994. Potassium replenishment capacity of illitic soils at their minimal exchangeable $\mathrm{K}$ in relation to clay mineralogy. Zeitschrift Pflanzenernahr Bodenkunde 157:467-470.

Sparks, D.L. 1987. Potassium dynamics in soils. Adv. Soil Sci. 6:1-63.

Stockdale, E.A., M.A. Shepherd, S. Fortune, and S.P. Cuttle. 2002. Soil fertility in organic farming systems-Fundamentally different? Soil Use Mgt. 18:301308.

U.S. Department of Agriculture. 2007a. The National Organic Program. I June 2007. <http://www.ams.usda.gov/ NOP>.

U.S. Department of Agriculture. 2007b. Crop nutrient tool. I June 2007. <http://npk.nrcs.usda.gov>.

Watson, C.A., H. Bengtsson, M. Ebbesvik, A.K. Loes, A. Myrbeck, E. Salomon, J. Schroder, and E.A. Stockdale. 2002. A review of farm-scale nutrient budgets for organic farms as a tool for management of soil fertility. Soil Use Mgt. 18:264-273.

Witter, E. and G. Johansson. 2001. Potassium uptake from the subsoil by green manure crops. Biol. Agr. Hort. 19:127141 . 